\title{
The affective economy of feminist leadership in Finnish universities: class-based knowledge for navigating neoliberalism and neuroliberalism ${ }^{1}$
}

\author{
Louise Morley ${ }^{* a}$ and Rebecca W. B. Lund ${ }^{b}$ \\ ${ }^{a}$ Centre for Higher Education and Equity Research (CHEER), University of Sussex, \\ UK; ${ }^{b}$ Centre for Gender Research, University of Oslo, Norway
}

\begin{abstract}
Women leaders are frequently treated as one class - a homogenised group with essentialised skills and competencies in binary relationship to male leaders. We explore how feminist ways of knowing gender and leadership, and circulations of affects, shape women's diverse leadership practices and identities within the neoliberal, and neuroliberal academy in Finland - a Nordic country with a sophisticated gender equality policy architecture. We debate the (re)production of social and material inequalities through epistemic injustice by exploring what possibilities are emerging from the assemblages and relational potential of policy interventions, global speaking back to patriarchal power, the revisioning of gender, and the inclusion of women in higher education leadership. Theoretically, the study intersects feminist affect notions, neoliberalism, neuroliberalism, and epistemic inclusion/injustice. We conducted ten interviews with middle-classed women university leaders in five universities. They described how, in the absence of possibilities to facilitate major structural changes, they applied their feminist knowledge and invested affective labour in the mediation of neoliberal and neuroliberal cultures. The politics of representation - counting more women into neoliberal universities, as one class, is not, we conclude, a counter-normative force. We need to consider how to apply feminist knowledge for leading post-gender universities and imagining alternative futurities.
\end{abstract}

Keywords: Finland; affect; feminist leadership; Higher Education; epistemic inclusion

\section{Introduction: rejected or rejecting women}

Policy initiatives and global debates on women and leadership often focus on gender as a demographic, representation, and quantitative change (Madsen, 2017). While equality of opportunity in employment is essential, it is only one aspect of complex narratives that are frequently deconstructed drawing upon stale, tired arguments of

\footnotetext{
${ }^{1}$ We should like to thank the ten interview participants for their time, insights, and wisdom, and the University of Tampere, the Academy of Finland, and the University of Sussex for their contribution to funding this project.
}

*Corresponding author's email: L.Morley@sussex.ac.uk 
essentialism and exceptionalism about women's leadership styles, and allegedly superior interpersonal and communication skills, or linear progress narratives and cliched metaphors such as pipelines and glass ceilings (Moratti, 2018). ${ }^{1}$ We need to consider how we 'do' gender in the academy, in everyday practices, processes and transactions, and move beyond the conceptualisation of women leaders as one class or category of analysis. A dominant representation of higher education is as a contemporary time-space damaged beyond repair by neoliberalism (Bacevic, 2019). Gender has been simultaneously miniaturised, as it is not an indicator in most audits in the global prestige economy, and magnified via MeToo initiatives, the Gender Pay Gap, and explorations of how neoliberalism reinforces areas where hegemonic masculinities have traditionally triumphed (Morley, 2018). This is evocative of McRobbie's (2004) argument that in Western post-industrial countries, feminism is involved in a 'double entanglement', where it is simultaneously 'taken into account' and 'repudiated' (p. 256). Gender has also been de-binaried and queered (Hines, 2018), questioning whether we should expand our understanding of gender beyond reductive, homogenising binaries of women and men.

Our article addresses whether and how feminists are able to bring new knowledges into their leadership practices? Or indeed, if desirable leadership skills and competencies are embedded in middle-class gendered communication practices. Furthermore, we ask what interventions and disruptions women leaders are able to make in the context of contemporary neoliberal and classed universities? Difference, in terms of being a newcomer to university leadership, can be generative in offering a fresh and desirable evaluative gaze. However, it can also entail pejoration, othering and disqualifications. For Haraway (1985), some differences are playful, while others are poles of world-historical systems of domination. The category of 'women leaders' is an imagined community, without the unity that the signifier implies. The performative political signifier places pressure of expectations that can only disappoint, and leaves participants with an 'uneasy sense of standing under a sign to which one does and does not belong' (Butler, 1993, p. 219). Ambivalent feelings of simultaneously belonging and not-belonging are described by Butler as disidentification - the notion that one identifies with a given subject position, e.g. woman or leader while at the same time feeling distanced from hegemonic or normative conceptions of what that identification might entail. A complex dialectic ensues of identification and counter-identification. Munoz (1999) challenged binary identifications and counter-identifications, and suggests that the third term disidentification is a mode of response to being on the receiving end of the violence (symbolic or actual) inflicted by hegemonic norms, and can occur when minority subjects feel disempowered in representational hierarchies. Disidentification, as a structure of identity-formation, can be a form of subversive performative citation or re-working of hegemonic norms, rather than simple opposition to those norms. This is evocative of Laclau and Mouffe's (2001) theory of rearticulation which refers to the capacity of signifiers to have their meanings altered in ways that hegemonic norms or understandings of particular issues can be undone and redone. Women leaders can feel pressured or can desire to disavow their identification as women, i.e., abject, inauthentic leaders, and also their identification as leaders, i.e., hegemonic males.

This article builds on Morley \& Crossouard's (2016a, 2016b) South Asian research, which explored the social and material disqualification of women leaders. For this article, we have selected the geopolitical context of Finland with its sophisticated gender equality policy architecture (Holli \& Kantola, 2007), raising questions about the agency of place and people's capacity to act. Theoretically, both 
projects engage with feminist affect theory (Ahmed, 2010), Butler's gender performativity (1990), and disidentification (1993), and neoliberalism in the prestige economy of the global academy (Lund, 2018; Morley, 2018). However, the Finnish study also explored theories of epistemic injustice, flagging the significance of feminist knowledge in our analysis of gender, women and leadership (Fricker, 2007).

\section{Class-free gender equality?}

We are aware of the perils of Nordic exceptionalism, and the need to be sensitive to the differences within imagined promised lands. In Finland, over half the population belong to the lower/upper middle-class (Melin, 2020), and Finnish Universities play a significant role in the reproduction of the middle-class (Käyhkö, 2015). Almost a century of progressive taxation and economic redistribution through Nordic welfare states has resulted in relatively small wealth and income gaps (increasing the past 10 years following the financial and economic crisis of 2008) (OECD, 2019). Political investment in progress towards eliminating the consequences of social class and enabling social mobility through tax-funded education, health care, trade unions in the negotiation of wage, working conditions, and unemployment benefits, has resulted in social class losing its discursive significance as a category of difference. Social class has not been a policy priority since the collapse of the Soviet Union in 1991, the rise of the competitive neoliberal state, and the individualised ethos following it (Pedersen, 2011). While differences in social class culture and geographic segregation in terms of economic advantage certainly exist in Nordic countries, the differences and struggle often take on a more subtle expression than would be the case in the UK (Hey, Leaney, \& Leyton, Forthcoming; Jones \& Maguire, Forthcoming). This is partly because Nordic upper-/middle-class elites adhere to an ideal of 'Elitist Egalitarianism' (Ljunggren, 2017) in which socio-economic privilege and cultural capital advantage are downplayed in the public realm. Moreover, a relatively ethnically and culturally homogenous population and ethnically unaware selfunderstanding (e.g., the Nordics narrated as benign colonisers (Sweden and Denmark), or as victims of and uncompliant with colonial logics (Norway and Finland), has meant that race has not historically been part of political consciousness as a significant category of difference (Keskinen et al., 2016). Gender has been prioritised as the main line of division and injustice in Nordic societies, and has become an export commodity and a badge of distinction (Husu, 2000). Very seldomly, gender struggles and norms are intersected with social class, despite the problem-identification and policy solutions being based on unspoken middle-class assumptions, values and solutions (Eisenstein, 2009).

In Finland, the Government Action Plan for Gender Equality 2016-2019 includes 30 measures that each ministry has responsibility to implement in their area of jurisdiction. Concerns include work-life balance, equal pay and reduction of gender segregation in work and education. A working group supports and monitors implementation, and ministries regularly assess impact measures. However, the latest gender equality statistics (2018) - published every second year by Statistics Finland note that women constitute $12.5 \%$ of rectors (vice-chancellors) (2 out of 16), and 29\% of the professoriate (728 out of 2513). While the research funding body - the Academy of Finland achieved 50\% female Research Council chairs and members, $31.7 \%$ of research funding went to women professors (13 out of 41$)$. These gender imbalances are global and historic. Globally, feminist scholarship has elaborated the 
gendered academy, first concerning the lack of women altogether (Dyhouse, 1995), later the absence of women in senior positions (Husu, 2004); gendered epistemic hierarchies (Pereira, 2017); gendered pay gaps (Barbezat \& Hughes, 2005); sexual harassment (Morley, 2011); bullying and occupational stress (Alliance of Women in Academia, 2018); and intersections of gender with ethnicity, age, sexualities, and social class (Gabriel \& Tate, 2018; Hey, 2003; Mintz \& Rothblum, 2013). Ahmed (2012) suggests that in naming the problem, you become the problem. Challenging positive (and marketised) attributes attached to the organisation by questioning its progress in gender equality is risky. We explore whether women leaders bring their feminist knowledge to bear in their leadership practices; more specifically how they identify and disidentify with values, subjectivities and policy imperatives within the contemporary academy.

The relationship between gender and higher education leadership is complex and contradictory. The lack of senior women leaders suggests discriminatory recruitment, selection, and professional development practices (van den Brink et al., 2010). However, leadership itself is not always an object of desire (Morley \& Crossouard, 2016a, 2016b). It is often perceived as the implementation of an assemblage of globally circulating neoliberal policy measures and cultural regimes that privilege performance, price, and profit. This dystopian reading positions leadership as a predetermined script involving compliance with a political economy that conflicts with many feminist value systems and epistemologies, while remaining associated with particular types of masculinities and masculinised authority (Blackmore, 2017). In our study, women were keen to disidentify with the political economy of neoliberalism which contrasts with feminist utopianism (Cooper, 2014). However, utopianism can rely on linear notions of progress and hegemonic ideas of what constitutes the good life and desirable futures. It might be naive to assume that feminism can transcend the neoliberal academy, but what kind of legitimacy and possibilities reside in feminism that point towards a transformation of the knowledge industry? We draw on the theoretical resources of Coady (2010), Dotson (2011), Fricker (2007), and Grasswick (2017), to explore epistemic (in)justice, and suggest that the concepts of testimonial and hermeneutical injustice can help analyse how women leaders' feminist knowledge of gender, inequity and leadership, and the alternative futurities these entail, become positioned within the neoliberal academy.

\section{Epistemic inclusion: whose/what knowledge counts?}

Fricker's (2007) work on epistemic injustice explores how certain individuals particularly from marginalised social groups - are not recognised as knowers, nor ascribed epistemic status. Epistemic exclusions produce deficiencies in social knowledge and create an affective economy of low-trust and disrespect. Lack of recognition has hermeneutical and testimonial dimensions. Testimonial Injustice refers to the systematic or incidental disregard of individuals' knowledge, as a consequence of their designated identity position. Women may be discredited as knowers by people holding sexist and misogynist prejudice. In this analysis, women's words, views, testimonies and belief systems do not carry the same weight as those of men in their equivalent social class. An example of Testimonial Injustice can be seen in sexual harassment and rape cases in which women's accounts are frequently disbelieved and conviction rates are low (Laugerud, 2019). Knowers who perpetrate 
testimonial injustice hold ethically bad affective investments in negatively stereotyping another group (Dotson, 2011).

Hermeneutical Injustice refers to the inability of making sense of knowledge claims due to a gap in interpretive resources. Without a concept of gender as a social and cultural construction, it would be difficult to challenge naturalised and essentialised understandings of masculinity and femininity, and this could in turn contribute to continued testimonial injustice. For Fricker (2007), epistemic injustice is harmful because it maintains ignorance at individual and systemic levels. She argues for the moral and virtuous values of epistemic justice and inclusion, suggesting that epistemic inclusion first and foremost takes place at individual levels. Dotson (2011) added the notion of testimonial smothering to Fricker's framework, arguing that some people choose to remain silent because of an expectation that they shall not be understood or recognised. This involves truncation in order to ensure that testimonies only contain content for which one's audience demonstrates testimonial competence.

Coady (2010) distinguished between discriminatory injustice and redistributive injustice. While Fricker's framework focuses on discriminatory aspects, it does not regard structural differences in terms of access to epistemic resources of education and information, as rehearsed in the decolonizing the curriculum debates (Begum \& Saini, 2019). The exclusion of certain concepts, theories, histories and experiences from study programmes is injustice towards the people whose insights and histories have been excluded. It can also be a source of injustice towards those who have not received these insights, because they are kept ignorant (Connell, 2007). For Grasswick (2017), the problematic forms of epistemic injustice are trust and participation. Epistemic trust injustice occurs when members of marginalised groups are not considered as able to live up to dominant scientific criteria. Participatory epistemic injustice occurs when someone is rejected from participation in knowledge creation and development and their questions, comments and ideas are not taken seriously.

Epistemic injustice is relevant for understanding the positioning of feminist knowledge in leadership within the political economy of contemporary academia. While moral and individual virtues are significant, they are insufficient to understand how epistemic injustice and exclusion are (re)produced or resisted (Koskinen \& Rolin, 2019). We suggest considering how feminist imaginaries and resistance enter leadership through cracks in relational orders of power (Coleman \& Ferreday, 2010). We explore how affective labour becomes a mode of including class-based feminist knowledge in leadership within the neoliberal academy. In the context of the Finnish gender system, this might both reproduce hegemonic notions of leadership and gender, and point towards new imaginaries.

\section{Conducting feminist research}

Finland does not have elite universities, as in the USA, UK, or France, and provides tax-funded education for all, but it does have a classed prestige economy, bound to the history, research intensity, and location of the institution. Finland's higher education system comprises 13 research-intensive universities, and 23 universities of applied sciences. The research-intensive universities are largely middle-class organisations that in subtle ways promote middle-class codes of communication, values of individual self-realisation via work (Andersen \& Aarseth 2012), and normalise 
particular forms of cultural and social capital which become significant in the aspirations and evaluation of academics (Käyhkö, 2015), and academic leaders. Normative gender ideals, as they play out in academia are also middle-classed, involving particular ability to narrate an individuated sense of self and achievements, emotional self-control, and investment in particular feminised ideals of care and selfsacrifice (Skeggs, 2004).

We conducted 10 semi-structured interviews in 2018-2019 with research directors, heads of department, deans and a vice-president in five of Finland's largest universities. Eight were full professors, aged from 40-65, with disciplinary backgrounds in humanities, social sciences, business and technology. All participants explicitly self-identified as women and feminists, and, with the exception of one, all identified as heterosexual. All were white, and identified as either born into middleclass social positions or became culturally and economically middle-classed via entry into academia. Women were asked about their interpretations, challenges, approaches, aspirations, and perceptions of senior leadership, engaging critically with what and how women are being asked to lead. The 90-minute interviews were conducted in English, and were recorded and transcribed. We use pseudonyms and purposefully omit details about discipline and university to protect anonymity.

Table 1.1 Participants

\begin{tabular}{|c|c|c|}
\hline Pseudonym & Job Title & Age range \\
\hline Liisa & $\begin{array}{l}\text { Professor } \\
\text { Dean }\end{array}$ & $60-65$ \\
\hline Päivi & $\begin{array}{l}\text { Professor } \\
\text { Head of Department }\end{array}$ & $60-65$ \\
\hline Salla & $\begin{array}{l}\text { Professor } \\
\text { Vice-Dean }\end{array}$ & $40-49$ \\
\hline Saija & $\begin{array}{l}\text { Professor } \\
\text { Head of discipline } \\
\text { Former: Vice-Dean, Dean, member of University Council and } \\
\text { Faculty Council }\end{array}$ & $60-65$ \\
\hline Hanna & $\begin{array}{l}\text { Professor } \\
\text { Research Director }\end{array}$ & $60-65$ \\
\hline Saari & $\begin{array}{l}\text { Assistant Professor } \\
\text { Head of Discipline }\end{array}$ & $40-49$ \\
\hline Mari & $\begin{array}{l}\text { Professor } \\
\text { Head of Discipline }\end{array}$ & $40-49$ \\
\hline Mirka & $\begin{array}{l}\text { Professor } \\
\text { Vice-Dean }\end{array}$ & $50-59$ \\
\hline Elina & $\begin{array}{l}\text { Professor } \\
\text { Vice President }\end{array}$ & $40-49$ \\
\hline Riikka & $\begin{array}{l}\text { Associate Professor } \\
\text { Head of Discipline }\end{array}$ & $50-59$ \\
\hline
\end{tabular}

Our research team combined Lund's insider knowledge of the Nordic countries with Morley's external analytical gaze, and age and career-stage variation, different sexual orientations, social class, and disciplinary and national locations. We read and coded the interview transcripts and, drawing on a thematic analysis approach (Clarke \& Braun, 2016; King \& Brooks, 2017), we identified, coded, and reviewed themes together, and exchanged ideas about literature, theories, and concepts that we believed relevant to deepening analysis. In so doing, we were able to activate our respective 
positionalities, not least with regard to noticing the dynamics of normative leadership, class, gender, sexuality and age that were at times expressed by our participants. We acknowledge that Finland is discursively positioned as a promised land of gender equality, and, as in many of the Nordic countries, the state and its public sector employers are visioned and experienced as benign, supportive and pro-citizen (Morley et al., 2018).

A key finding from both the South Asian and Finnish projects is that women are being rejected or disqualified from senior leadership as a class through discriminatory recruitment, selection and promotion procedures, gendered career pathways, and exclusionary networks and practices in women-unfriendly institutions. Those who were entering leadership in South Asia were often from privileged socio-economic backgrounds, often with dynastic advantage. However, many women in South Asia and Finland were refusing, resisting, or dismissing senior leadership and making strategic decisions not to apply for positions which they evaluated as onerous and undesirable. While women leaders in Finland enjoyed the creative and developmental aspects of leadership, they also outlined areas of challenge and affective intensity. The following sections investigate some of the discourses, identifications, and disidentifications that underscore the process of women being and becoming leaders in higher education.

\section{Navigating neoliberalism and intellectualism: pleasures and tensions, love and lack}

Participants in Finland reported intense pleasure in leadership - enabling, facilitating, recognising, and including their colleagues. However, narratives often articulated lack - of resources in austerity cultures, transparency in decision-making, research time, formal support, training, and development, work-life balance, and control and power/influence. The cumulative lacks led to an absence of desire for and a disidentification with more senior leadership. Tensions included interest representation and cognitive and affective dissonance between their own feminist knowledge-informed values and the neoliberal practices that they were forced to enact - or 'standing under a sign to which one does and does not belong' (Butler, 1993, p. 219). For many, the sign was the performative prestige economy precipitated by the political economy of neoliberalism, and the ensuing globally circulating cluster of policy measures. Making academic labour, activity and productivity intelligible via metrics and norms was creating and promoting ontological antagonisms, which resulted in testimonial smothering (Dotson, 2011), and participatory epistemic injustice (Grasswick, 2017). Women had to disidentify, suppress, or silence their feminist knowledge in order to comply with the reductive and often positivistic performance indicators of audit. Accountability and accountancy had affective implications, as Liisa illustrated:

Measuring in general bothers me because we are dying from all the measuring. You don't know how much information I for example get from different measures from our headquarters of the university ... I'm critical to measuring in general, yes.

A question is whether feminism and university leadership are oppositional, with feminists who enter leadership constructed as class traitors to the wider social movement and complicit with establishing and maintaining monolithic neoliberal cultures. Hanna voiced this tension: 
I think for the most part those kinds of jobs are now constructed in such a way that feminists wouldn't like to be part of it ... And once you do join that club and become vice-chancellors and senior managers, you can no longer be a sister.

Financialisation, or the cultural and material regime and governing rationality that privileges price and profit and measures all activities in monetary terms (Brown, 2015) had embodied affects, as Païvi described:

This is a very neoliberal university so I also have a responsibility of all this money ... I had this bad feeling in the morning in my stomach ... Sometimes when I am sitting in meetings where we are talking about the strategies and all that neoliberal stuff, I get sick, I feel sick.

The collision between feminist sensibilities and neoliberal priorities meant that this participant had to occupy a troubling leadership (embodied) space. Whereas some feminist knowledge, i.e., not the neoliberal feminist brand (Rottenberg, 2018), emphasises the social and collective (Eisenstein, 2009), the neoliberal academy values competitive individualism. Competition was thought to erode solidarity, and the displacement or replacement of the collective and the collegial with the emphasis on heroic individualism produced success/ failure narratives that overlooked the larger system. This was exacerbated by the demise of knowledge contributed by democratised collegiality and its replacement with centralised and managerially driven decision-making, as Saija observed: 'The management of the university has changed, and not in a more democratic direction. Small groups of leaders are making the decisions affecting everyone.'

A further collision was between critical disciplinary knowledge and leadership compliance. Academic and leader identity clashes occurred on the cusp between being an academic and being a leader. This tension was informed by middle-class investments in self-realisation through work. While intellectual work was perceived as allowing self-expression and self-realisation, leadership was enmeshed in neoliberal practices with which they disidentified. Our participants identified as intellectuals whose scholarship had been interrupted, disrupted, and delayed by their leadership roles. Disciplinary knowledge and leadership knowledge were often cognitively separated, and expressed in the temporality of lack of research time, as explicated by Liisa:

I'm a researcher by heart. And that is why I get stressed ... if you want to write, you need time to think and read. In my current position, with all the leadership responsibilities, I am in a position where I only have time to read and edit other people's writing.

The difference in temporality between leadership and meaningful academic processes was a source of tension in the accelerated neoliberal academy. Leadership involved accepting neoliberalism as inevitable and recasting everything in its logic, and as such became an expression of discriminatory and redistributive epistemic injustice. Possibilities of thinking differently and imagining leadership and the university otherwise were smothered. While slow scholarship for more in-depth knowledge creation is being resurrected (Stengers \& Muecke, 2018), this is a chimera for most academics and leaders. For some participants, leadership was a form of knowledge-suppressing turn-taking in the domestic economy, and one that was accompanied by substantial amounts of anti-intellectual clutter, and indeed, anxiety (Brunila \& Valero, 2018). 


\section{Neuroliberalism: governing through anxiety}

Neuroliberalism is a constellation of behaviourism, neuroscience and economics. It is '[a] rationality of government that takes its subject as the neurotic citizen and involves an orchestrated attempt to govern through neurosis' (Isin, 2004). It unites neoliberal systems of government with psychological expressions of power and influence (Whitehead et al., 2018). Underpinning it is a desire to govern behavioural externalities AND internalities. This can result in structural problems solved by viewing them as behavioural e.g., the current mental health 'crisis' in higher education has produced a range of micro and meso-level interventions including mindfulness and resilience training, animal companions (Coughlan, 2019), and increased spending on counselling services (Barrable et al., 2018). What is left undertheorised is the macro socio-political context of the neoliberal and neuroliberal university that promotes shame, precarity, self-doubt, and insecurity as normative organisational, learning, motivational, and employment regimes (Shajahan, 2019).

Given the many sites of gendered discomforts, what difference were the 10 female leaders able to make? Mari cited modelling textbook class-based knowledge of work/life balance, including 'not working in evenings or weekends', 'supportive of people taking a lot of holidays'. Influence also related to applying feminist knowledge to community-building and changing the affective economy, as Saari explained: 'A lot of it is domestic work related to reproducing the institution. But a lot of it is also about building a community and sense of belonging.'

Riikka interpreted feminist leadership as an ethical transformation of the toxic organisational cultures that financialisation and competition had created:

Being feminist refers here to inclusiveness ... and also the ethics of leadership and the facilitation of resources. Not just in terms of money, but creating a sustainable work environment in which people can actually work, rather than a negative atmosphere.

Participants frequently described their feminist change interventions in terms of relational leadership. Feminist knowledge involved mentoring, soothing, reassuring, and cognitively restructuring colleagues who had been damaged by the psychic life of power (Butler, 1997). Saari believed that: '(Women) think they have to be twice as good. So, I need to support and encourage them, tell them that they are good.'

Mirka stressed the importance of effective communication skills: 'I spend a lot of time communicating to people and writing e-mails and speaking to them and trying to get the tone right.'

Managing the affective ecology was seen as crucial by Päivi, as this influenced academic identities, and indeed, performance: 'Affects are something that make people feel smaller or bigger. Fear makes people feel smaller. Love and enthusiasm makes you feel bigger.'

Mentoring was constructed by Hanna, as the intervention that would cut through affective dissonance:

'I felt really guilty ... one associate professor came and asked for a mentoring scheme because of problems with stress. I realised that I hadn't appreciated how bad some people felt ... how deep their anxieties were. So, we set up a mentoring scheme.

Morley (2013) argued that mentorship, or the re-distribution of organisational and professional knowledge and social capital, has been perceived as a winning formula 
for women's career development, but is often aimed at assimilating women into dominant masculine corporate cultures (McKeen \& Bujaki, 2007). For Hanna, mentoring was aimed at the need to undo, rather than reinforce, neoliberal performance indicators: 'I want the output to be them as great professors rather than quantifiable research grants and papers.' A hidden discourse in mentoring narratives was age - especially in relation to other structures of inequality such as gender, class, and sexual orientation, with older women valued mainly for their ability to build the capacity of others.

\section{Broken down by sex and age}

Only one participant identified as lesbian, and our data were saturated in heteronormative and gender-binaried metaphors and exemplars - especially of the morality of care and the heterolinearity of conventional life choices. Leadership was often equated with care, involving middle-classed, essentialised and overloaded mothering skills, and reprofuturism of heteronormative temporal schemas (Dinshaw et al., 2007; Skeggs 2004), as Saari illustrated: 'It is a bit like mothering and it also includes ensuring funding. I need to ensure that people for instance publish in their own name and that they apply for docentships'. ${ }^{2}$

Doctoral supervision was sometimes encoded in the language of reproduction as demonstrated by Liisa: 'Women are expected to become like mothers ... I have produced maybe 14 children into the world, my researchers.' Mothering was interpreted as relational and also as sacrificial, linked to prioritising the collective institutional housework over pursuing individual research passions. Those who avoided their turn-taking as leaders were constructed as draft-dodgers! Or more troubling, in the language of neuro-diversity (and heteronormative family discourse), by for instance Saari: 'Our system rewards people who are not teaching and are not doing the institutional and domestic work ... it rewards basically autistic people that have no family and just work and write.'

While leadership was sometimes imagined in reproductive terms, contradictorily, actual mothering was problematic, and some of our participants invoked a heteronormative temporality and reprofuturism, involving normative statements about the inevitability of reproduction in relation to women's careers, with a strong sense of causal succession between youth and fertility, as noted by Saari: 'Women of a certain age ... of the fertile age are not necessarily recruited'.

A key part of middle-class parenting involves the sacrificial ethos and lifedenying martyrdom, as Riikka expressed: 'I asked, "How was your holiday?" And some senior people responded "Oh, I didn't take any holidays, because work is sort of my life", and this happened many times.' In the sacrificial and highly competitive academic affective ecology with its virility culture, holidays were seen as trivial distractions associated with the disqualified life of the body and emotions, and evidence of lack of commitment to the serious life of the mind. Paradoxically, a binaried gender performance (performing either as a (cis)man or a (cis)woman) was required in the workplace and this involved emotional literacy and affective labour. As Liisa suggested:

He's a young man. Too ambitious and too competitive, so he got somehow insulted or, became like angry because he wasn't chosen for the position ... I went to his room and started you know speaking, how is your child and, what is going on? ... At first he wasn't very 
happy at all, but then he started speaking ... First you smooth out the atmosphere, then you go into the issue.

This is evocative of Deutsch's (2007) argument about the expected leadership styles of older women, which involve establishing oneself as a non- threatening middle-class woman through talk of home and family. Is this gendered communication style humanising in toxic work cultures or a manipulative, neuroliberal, normative form of performance management and ethics of affirmation? Or indeed, is it a mode of self-minimisation for older women who are thought to have outstayed their welcome? Staying in the workplace beyond retirement age (when it exists) can be perceived as greedy, desperate and selfish. These negative social constructions can be tempered by sacrificial service to others.

Chronormativity implies the use of time to organise individual human bodies toward maximum productivity. The ordering of time reflects a logic of (hetero)normativity that delimits difference and temporality and is both a tool and marker of power (Freeman, 2010). Work/Life Balance was conceptualised by some participants as biological and reproductive, within a context of heteronormative time/space constructs. Ageing, class, and gender materialise in the context of waged work, with ageing often experienced through gender and class (Segal, 2013). Leadership knowledge about age is often limited. The older female worker is dismissed as a liability, a burden, rather than a resource. Within the political economy of ageing, and the policy problematisation of ageing populations, the ageing worker is reduced to a chronological figure, a problem to be managed - especially in relation to the removal of a Default Retirement Age (DRA) (ACAS, 2019). Morganroth Gullette (1997) argued that we are 'aged by culture'. Age is rarely discussed as a neutral signifier. Port (2012) suggests that 'the old have projected onto their bodies that which normative culture fears and represses within itself: the knowledge of eventual bodily failure and mortality' (p. 3). Laslett (1996) argues that when chronological age advances, the differences between individuals increase. However, rather than viewing older age as a knowledge advantage in the labour market, it tends to be associated with biological and cognitive deterioration, decay, and decline. For women, ageism, classism, and sexism intersect to dismiss them as always being the wrong age, or they are interpellated in hegemonic age-appropriate identities, e.g., older women as kindly guides and mentors to the younger ones, as Liisa explained:

It is easy to come to me to tell that they have a problem ... I have that kind of a mentor role, a respected elderly professional's mentor role. I think that the younger academics can come to me for career advice.

Heteronormativity worked to shape life and economic choices and courses, and possibilities for identification. Young women were seen to sometimes lack confidence and career capital (Gill \& Orgad, 2017), but to possess potential and ambition that had to be nurtured - so long as their (reproductive) bodies did not disrupt their progress. Gendered stereotypes abound in age studies as Irni (2010) reports 'younger men are assumed as arrogant and young women as too unsure of themselves'. Mari explained:

... there's a strong perception of being a young woman ... You have to prove your expertise and your capabilities. When you go to interview people in parliament, they think that you're a $\mathrm{PhD}$ student. But then it is considered a strength to be young in committee work.

Gendered and classed characteristics can become amplified with age, and positioning is achieved by making contrasts. Age is highly performative, and (anti) 
ageing is yet another individual project involving extensive investment and disciplinary body-work - a technical problem to be solved by self-maximising entrepreneurs of the self. Older, post-menopausal women navigated a limiting path between being wise mentors and date-expired 'bedblockers' who sometimes needed to disguise age by surrounding themselves with youth - a potentially sexualising problematic. Liisa had received a tip: 'A retired colleague of mine ... she told that I know a way how you stay visible. And one way is to have always beautiful young doctoral students around you.'

Distancing oneself from older people and opting for the semiotics of youth can be understood both as a form of internalised oppression and also as resistance to ageism, and disidentification with the ageing process. Ageing women are not just bodies, it seems, but are constructed via practices, norms and materialities in the workplace. If bodies cannot be changed, then maybe the practices can?

\section{Conclusion: making a difference to difference}

Our participants were located in liminal spaces between their feminist knowledge and the operations of the neoliberal university. We found that Testimonial Injustice occurred in the way in which the substantial feminist knowledge that women leaders brought to their roles was viewed and felt largely as class-based affective labour, i.e., mediating and applying understandings of power relations and systems to soothe, comfort, and reassure colleagues. Feminist analysis of the neoliberal financialised and marketised global academy and the way in which neuroliberalism had been developed to govern via anxiety were integrated into quotidian leadership practices. But this came at a cost to their knowledge creation and application, and was also frequently expressed in heteronormative and chrononormative terms. Additionally, authority does not always stick to women leaders (Morley \& Crossouard, 2016a, 2016b), and women needed to make substantial identity investments to establish their leadership credentials, capacity, and knowledge. Hermeneutical Injustice included lack of systemic understanding or support for how gender, age, class, and sexual orientation intersect in the academic workplace, and the disqualification of alternative ways of governing academic life. Testimonial smothering and participatory epistemic injustice occurred because participants could not explicitly express feminist ideas in their leadership practices, as they did not perceive this as being understood or recognised within the neoliberal university. Discriminatory injustice and redistributive injustice existed in participants' narratives as an inherent feature of the neoliberal and neuroliberal university. Neoliberalism was spoken of as inevitable, largely without possible alternative imaginaries. Any possibility of thinking differently about the organisation of the university would have to be recast in the discourse and logic of neoliberalism to be acceptable (e.g. self-help/ personal development/ wellbeing). Concerns about gender equality were often separated from feminism. In that way the neoliberal discourse and ideology, permeating the organisation, effectively hindered the (re)distribution of resources for thinking differently and challenging dominant structures. Epistemic trust injustice occurred because some of the women leaders we spoke to, in their narratives about themselves and others, unintentionally reproduced the notion that women could not meet the dominant performance indicators without substantial emotional support, in part based on heteronormative and ageist assumptions about lifecourse. 
The politics of representation, i.e., counting more middle-classed (cis)women neuroliberally into neoliberal universities, we argue, should be replaced with a politics of hope and vision for a post-gender, post-class university (Coleman \& Ferreday, 2010). Theorising the affirmative does not necessarily involve the loss of critical edge and a degeneration into 'New Age' fatalism or positivity (Ehrenreich, 2009). Rather, it is a recognition that hope and hopelessness 'do' something. Critical hope is a potent form of resistance (Bozalek et al., 2014; Colebrook, 2010). Our participants' affective interventions to counter the corrosive effects of the neoliberal and neuroliberal academy were a form of epistemic inclusion, an act of critical hope about different futures. These could be extended to include a broader range of class-based gender identities.

We have questioned what interventions and disruptions women leaders are able to make along the lines of what Manning and Massumi (2014) would classify as structured improvisations. We suggest that feminist knowledge and feminist leadership involves refusing to consent to the 'truth' of neoliberalism. The 'crisis' of feminism, resulting from the neoliberal co-opting and mainstreaming of gender equality politics, reducing it to numerical representations of women and gender binaries, does not have to result in hopelessness. This is an opportunity to re-imagine and reconfigure what feminism(s) and feminist leadership could and should be about: this is made a possibility because non-hegemonic identities are entering positions of leadership. Hope is not to be conflated with cruel optimism (Berlant, 2011), but is rather about orienting present 'affective drives and energies' (Massumi, 2002, pp. 211-212), by seeing the potential for change in a given situation. Engaging with leadership practices and knowing through the lens of epistemic injustice and inclusion may be a starting point for such imagination and actualisation. Acknowledging and critiquing the individual and structural dimensions of epistemic injustice is a first step towards change, but the diverging concepts, we presented earlier, also point towards what needs to happen - to where hope and imagination might dwell. Thinking of what testimonial justice might entail, feminist knowledge should not be reduced to classbased affective labour of soothing, comforting, and reassuring anxious colleagues struggling to survive in the neoliberal university, but should be used effectively to rethink, together with those colleagues, what the good academic organisation and working life could be instead. As such what is often designated unpaid, invisible, and unrecognised affective labour of women leaders, could become central in informing what leadership ought to entail in a manner that both integrates and transgresses that which is categorised as 'feminine'.

This points in turn to the need for fostering a culture and modes of knowledgesharing that ensure better understanding for how gender, age, class, ethnicity, and sexuality intersect in the workplace and lead to the disregard for non-hegemonic ways of knowing what academic work and leadership might entail. This would also include countering epistemic smothering and furthering democratic contribution of alternative knowledge. The organisational and managerial logics of neoliberalism and neuroliberalism effectively work to impede democratic debate and circulation of ideas for doing and knowing otherwise. We need to create democratic feminist fora, across strands of difference, in which we place emphasis on sharing experiences, ideas, and resources for how to effect change, in a way that does not reproduce stereotypes, but challenges and contradicts them. A key question is how feminist leadership knowledge can be used for imagination and actualisation, rather than mitigation. 


\section{Notes}

${ }^{1}$ We revised this article in the midst of the global Covid-19 pandemic. Finland had a female prime minister, Sanna Marin. She, along with other female heads of state, e.g., Taiwan's Tsai Ing-wen; New Zealand's Jacinda Ardern; Germany's Angela Merkel; and Denmark's Mette Frederiksen, were widely acknowledged as being more effective at managing the virus and keeping mortality and infection rates low (Henley \& Roy, 2020). This line of argumentation overlooked the political fabric of the countries led by women, and suggested that women were innately better suited to crisis management.

2 Docentship, or Dossenti in Finnish, is an academic title awarded by universities in Finland. The English equivalent would be Adjunct Professor. Being awarded docentship does not involve any salary or employment assurance, but it does enable applying for large project funding, acting as PI in such projects, and acting as an opponent for $\mathrm{PhD}$ theses.

\section{References}

ACAS (2019). Age discrimination: Key points for the workplace. https://archive.acas.org.uk/media/6118/Age-discrimination-key-points-for-theworkplace/pdf/Age discrimination key points for the workplace.pdf. Accessed 9 January 2020.

Ahmed, S. (2010). The promise of happiness. London: Duke University Press.

Ahmed, S. (2012). On being included: Racism and diversity in institutional life. Durham: Duke University Press.

Alliance of Women in Academia (2018). Tackling sexual harassment and bullying in Higher Education: Towards a more comprehensive response. 13 May 2018, LSE Blogspot: Engenderings. https://blogs.1se.ac.uk/gender/2018/05/30/tackling-sexual-harassment-and-bullying-in-highereducation-towards-a-more-comprehensive-policy-response/. Accessed 11 June 2019.

Andersen, L. C. \& Aarseth, H. (2012). Den likestilte familien i et klasseperspektiv. Ellingsceter, Anne Lise og Karin Widerberg (red.). Velferdsstatens familier. Nye sosiologiske perspektiver. [Families of the welfare state: New sociological perspectives]Oslo: Gyldendal Akademisk. S, 191-214.

Bacevic, J. (2019). Knowing neoliberalism. Social Epistemology, 33(4), 380-439.

Barbezat, D. \& Hughes, J. (2005). Salary structure effects and gender pay gap in academia. Research in Higher Education, 46(6), 621-640.

Barrable, A., Papadatou-Pastou, M., \& Tzotzoli, P. (2018). Supporting mental health, wellbeing and study skills in higher education. International Journal of Mental Health Systems. https://doi.org/10.1186/s13033-018-0233-z

Begum, N. \& Saini, R. (2019). Decolonising the curriculum. Political Studies Review, 17(2), 196201. https://doi.org/10.1177/1478929918808459

Berlant, L. (2011). Cruel optimism. London: Duke University Press.

Blackmore, J. (2017). Leadership in higher education: A critical feminist perspective on global restructuring. In S. Wright \& C. Shore (Eds.), Death of the public university? (pp. 90-113). New York: Berghahn Press.

Bozalek, V., Leibowitz, B., Carolissen, R., \& Boler, M. (Eds). (2014). Discerning critical hope in educational practices. London: Routledge.

Brown, W. (2015). Undoing the demos neoliberalism's stealth revolution. New York: Zone Books.

Brunila, K. \& Valero, P. (2018). Anxiety and the making of research(ing) subjects in neo-liberal academia. Subjectivity, 11(1), 74-89.

Butler, J. (1990). Gender trouble. London: Routledge. 
Butler, J. (1993). Bodies that matter. London: Routledge

Butler, J. (1997). The psychic life of power: Theories in subjection. Stanford: Stanford University Press.

Clarke, V. \& Braun, V. (2016). Thematic analysis. In E. Lyons \& A. Coyle (Eds.), Analysing qualitative data in psychology (pp. 84-103), 2nd ed. London: Sage.

Coady, D. (2010). Two concepts of epistemic injustice. Episteme, 7(2), 101-113.

Colebrook, C. (2010). Toxic feminism: Hope and hopelessness after feminism. Journal for Cultural Research, 14(4), 323-335.

Coleman, R. \& Ferreday, D. (2010). Introduction: Hope and feminist theory. Journal for Cultural Research, 14(4), 313-321.

Connell, R. (2007). Southern theory. Cambridge: Polity.

Cooper, D. (2014). Everyday utopias. The conceptual life of promising spaces. Durham and London: Duke University Press.

Coughlan, S. (2019). Dogs 'prevent stressed students dropping out'. https://www.bbc.co.uk/news/education-48806935. Accessed 9 January 2020.

Deutsch, F. (2007). Undoing gender. Gender and Society, 21(1), 106-127.

Dinshaw, C., Edelman, L., Ferguson, R., Freccero, C., Freeman, E., Halberstam, J., Jagose, A., Nealon, C., Tan Hoang, N. (2007). Theorizing queer temporalities: A roundtable discussion. GLQ A Journal of Lesbian and Gay Studies, 13. doi: 10.1215/10642684-2006-030

Dotson, K. (2011). Tracking epistemic violence, tracking practices of silencing. Hypatia: Journal of Feminist Philosophy, 26(2), 236-257.

Dyhouse, C. (1995). No distinction of sex? Women in British universities 1870-1939. London: Taylor and Francis.

Ehrenreich, B. (2009). Bright-sided: How the relentless promotion of positive thinking has undermined America. New York: Metropolitan Books.

Eisenstein, H. (2009). Feminism seduced. London: Routledge.

Freeman, E. (2010). Time binds: Queer temporalities, queer histories. London: Duke University Press.

Fricker, M. (2007). Epistemic injustice: Power and the ethics of knowing. Oxford: Oxford University Press.

Gabriel, D. \& Tate, S. A. (Eds.). (2018). Inside the ivory tower: Narratives of women of colour surviving and thriving in British academia. London, UK: Trentham Books/UCL IOE Press.

Gill, R. \& Orgad, S. (2017). Confidence culture and the remaking of feminism. New Formations, 91, $16-34$.

Grasswick, H. (2017). Epistemic injustice in science. In I. A. Kidd, J. Medina, \& G. Pohlhaus (Eds.), The Routledge handbook of epistemic injustice (pp. 313-324). London: Routledge.

Haraway, D. (1985). A manifesto for cyborgs: Science, technology, and socialist feminism in the 1980s. Socialist Review, 15, pp. 65-107.

Henley, J. \& Roy, E.A. (2020). Are female leaders more successful at managing the coronavirus crisis? https://www.theguardian.com/world/2020/apr/25/why-do-female-leaders-seem-to-be-moresuccessful-at-managing-the-coronavirus-crisis. Accessed 12 October 2020.

Hey, V. (2003). Joining the club? Academia and working-class femininities. Gender and Education 15(3), 319-336.

Hey, V., Leaney, S., \& Leyton, D (Forthcoming). The un/methodology of 'theoretical intuitions': Resources of generations gone before: thinking and feeling class. Discourse, 42(1). https://doi.org/10.1080/01596306.2020.1834953 
Hines, S. (2018). Is gender fluid? A primer for the 21st Century. London, New York: Thames and Hudson.

Holli, A. M. \& J. Kantola (2007). State feminism, Finnish style: Strong policies clash with implementation problems. In J. Outshoorn \& J. Kantola (Eds.), Changing state feminism (pp. 82101). London: Palgrave Macmillan.

Husu, L. (2000). Gender discrimination in the promised land of gender equality. Higher Education in Europe, 25(2), 221-228. doi: 10.1080/713669257

Husu, L. (2004). Gate-keeping, gender equality and scientific excellence. In D. Al-Khudhairy et al., (Eds.), Gender and excellence in the making (pp. 69-76). Brussels: European Commission.

Irni, K. (2010). Ageing apparatuses at work: Transdisciplinary negotiations of sex, age and materiality. Åbo Akademi University Press. http://urn.fi/URN:ISBN: 978-951-765-537-8

Isin, E. F. (2004). The neurotic citizen. Citizenship Studies, 8(3), 217-235.

Jones, L. \& Maguire, M. (Forthcoming). Investing ourselves: The role of space and place in being a working class female academic. Discourse 42(1). https://doi.org/10.1080/01596306.2020.1767937

Käyhkö, M. (2015). Working-class girls in a foreign land. Social class and settling into university in a cross-current between two cultures. Gender and Education, 27(4), 445-460.

Keskinen, S., Tuori, S., Irni, S., \& Mulinari, D. (Eds.). (2016). Complying with colonialism: Gender, race and ethnicity in the Nordic region. London: Routledge.

King, N. \& Brooks, J. (2017). Thematic analysis in organisational research. In C. Cassell, A. L. Cunliffe, \& G. Grandy (Eds.), The Sage Handbook of qualitative business and management research methods (pp. 219-236). London: Sage.

Koskinen, I. \& Rolin, K. (2019). Scientific/intellectual movements remedying epistemic injustice: The case of Indigenous studies. Philosophy of Science, 86(5), 1052-1063.

Laclau, E. \& Mouffe, C. (2001). Hegemony and socialist strategy: Towards a radical democratic politics $\left(2^{\text {nd }}\right.$ edition). London: Verso.

Laslett, P. (1996). A fresh map of life. The emergence of the third age. Second Edition. Houndmills \& London: Macmillan Press LTD.

Laugerud, S. (2019). Common sense, (ab)normality and bodies in Norwegian rape verdicts. NORA: Nordic Journal of Feminist and Gender Research. doi: 10.1080/08038740.2019.1697748

Ljunggren, J. (2017). Elitist egalitarianism: Negotiating identity in the Norwegian cultural elite. Sociology, 51(3), 559-574.

Lund, R. (2018). The social organisation of boasting in the neoliberal university. Gender and Education, 32(4), 466-485. doi: 10.1080/09540253.2018.1482412

Madsen, S. (Ed.). (2017). Handbook of research on gender and leadership. Cheltenham: Edward Elgar Publishing.

Manning, E. \& Massumi, B. (2014). Thought in the act: Passages in the ecology of experience. Minneapolis: Minnesota University Press.

Massumi, B. (2002). Navigating movements. In M. Zournazi (Ed.), Hope: New philosophies for change (pp. 210-242). Sydney: Pluto Press.

McKeen, C. \& Bujaki, M. (2007). Gender and mentoring. In B. R. Ragins \& K. E Kram (Eds.), The Handbook of mentoring at work: Theory, research, and practice (pp. 197-222). Los Angeles: Sage Publications.

McRobbie, A. (2004). Post-feminism and popular culture. Feminist Media Studies, 4(3), 255-264.

Melin, H. (2020). Finland is still a class society https://alusta.uta.fi/2020/02/21/finland-is-still-a-classsociety/ Accessed 2 October 2020. 
Mintz, E. \& Rothblum, E. (Eds.). (2013). Lesbians in academia: Degrees of freedom. London: Routledge.

Moratti, S. (2018). What's in a word? On the use of metaphors to describe the careers of women academics. Gender and Education. doi: 10.1080/09540253.2018.1533927

Morganroth Gullette, M. (1997). Declining to decline: Cultural combat and the politics of the mid-life. Charlottesville: University of Virginia Press.

Morley, L. (2011). Sex, grades and power in Higher Education in Ghana and Tanzania. Cambridge Journal of Education, 41(1), 101-115.

Morley, L. (2013). Women and Higher Education leadership: Absences and aspirations. Stimulus Paper for the Leadership Foundation for Higher Education.

https://www.lfhe.ac.uk/en/components/publication.cfm/MorleyST10

Morley, L. (2018). Gender in the neoliberal research economy: An enervating and exclusionary entanglement? In H. Kahlert (Ed.), Gender studies and the new academic governance. Global challenges, glocal dynamics, and local impacts (pp. 15-40). Wiesbaden: Springer VS.

Morley, L. \& Crossouard, B. (2016a). Gender in the neoliberalised global academy: The affective economy of women and leadership in South Asia. British Journal of Sociology of Education, 37(1), 149-168.

Morley, L. \& Crossouard, B. (2016b). Rejection, refusal, reluctance, revisioning: Women in Higher Education leadership in South Asia. Studies in Higher Education, 46(5), 801-814.

Morley, L., Angervall, P., Berggren, C., \& Dodillet, S. (2018). Re-purposing Fika: Rest, recreation or regulation in the neoliberalised Swedish university? European Journal of Higher Education, 8(4), 400-414.

Muňoz, J. E. (1999). Disidentifications: Queers of colour and the performance of politics. Minneapolis: University of Minnesota Press.

OECD (2019). Income inequality. https://data.oecd.org/inequality/income-inequality.htm). Accessed 2 November 2020.

Pedersen, O. K. (2011). Konkurrencestaten, 1. udgave, 5. oplag. København: Hans Reitzels Forlag. [The Competition State.]

Pereira, M. M. (2017). Power, knowledge and feminist scholarship. London: Routledge.

Port, C. (2012). No future? Aging, temporality, history, and reverse chronologies. Occasion: Interdisciplinary Studies in the Humanities, v. 4 (May 31), http://occasion.stanford.edu/node/98.

Rottenberg, C. (2018). The rise of neoliberal feminism. Oxford: Oxford University Press.

Segal, L. (2013). Out of time: The pleasures and perils of ageing. London: Verso.

Shahjahan, R. (2019). On 'being for others': Time and shame in the neoliberal academy. Journal of Education Policy. doi: 10.1080/02680939.2019.1629027

Skeggs, B. (2004). Class, self, culture. London: Routledge.

Statistics Finland (2018). Gender equality in Finland, 2018. Helsinki: Statistics Finland.

Stengers, I. \& Muecke, S. (2018). Another science is possible: A manifesto for slow science. Cambridge: Polity.

Van den Brink, M., Benschop, Y., \& Jansen, W. (2010). Transparency in academic recruitment: A problematic tool for gender equality? Organization Studies, 31(11), 1459-1483.

Whitehead, M., Jones, R., Lilley, R., Howell, R. \& Pykett, J. (2018). Neuroliberalism: Cognition, context, and the geographical bounding of rationality. Progress in Human Geography, 43(4), 632649 . 